\title{
Flexible Employment Forms as an Element of Flexicurity
}

\author{
Monika Grabowska \\ Wroclaw University of Economics \\ Department of Economics and Development Studies \\ Komandorska 118/120 \\ 53-345 Wroctaw, Poland \\ monika.grabowska@ue.wroc.pl
}

\begin{abstract}
Flexible employment forms are one of the elements of active labour market policy which is connected with flexicurity system. The new option on labour market in the present times. Results of the global economic crisis and the demographic situation related to ageing societies cause a need to implement solutions on the labour market which shall be both flexible and protective. Flexible forms of work are forms of work which deviate from the typical form of employment such as a permanent employment contract. These are atypical forms of employment whose characteristics include flexible working time and place, the form of employment, other relations between the employee and the employer. They are a truly new approach in the labour law as they more and more depart from the classical job under a permanent employment contract.
\end{abstract}

Keywords: labour market, flexible forms of work, forms of employment, traditional model of employment, flexicurity.

JEL Classification: J 22, Q 01.

\section{INTRODUCTION}

The globalisation phenomenon in the present times causes numerous fears in various countries, despite their social and economic development level. Almost day after day, globalisation has become the most urgent problem of our times, something discussed from conference rooms to newspapers and universities all over the world (Stiglitz, 2004, p.22). Economic processes resulting from that phenomenon are followed by numerous changes, including ones on the labour market, causing break of social bonds by growing unemployment. Societies in low and middle developed countries, Poland included, expect globalisation with human face, one which by changing the labour market shall contribute to improve the level of life for the whole of society. Such expectations induce an analysis of changes occurring on the labour market in globalisation conditions (Księżyk, 2005, p.288).

Results of the global economic crisis and the demographic situation related to ageing societies cause a need to implement solutions on the labour market which shall be both flexible and protective. Processes occurring on the labour market strongly impact the feeling of stability and welfare of households. The situation 
in this sector of the economy has been the subject of many political debates, media discussions and academic discourses. Discussions on the labour market reveal authentic dilemmas related to making a choice between flexibility and safety of citizens.

In the article, the author has stressed the meaning of flexible forms of employment in the present times, presented a concept of a model labour market that exists in Denmark and is recommended by the European Union. Attention should be paid to the fact that flexible forms of work make an important element of the flexicurity concept which contributes to modernisation of labour markets across Europe and to more effective meeting of globalisation challenges.

\section{FLEXICURITY AS A NEW MODEL OF THE LABOUR MARKET}

Across Europe labour markets change, the flexicurity model is being implemented. The model was created in Denmark as a reform programme for the labour market. The term flexicurity derives from the English language and was made of two words: flexibility (elasticity, susceptability) and security (safety, guarantee, protection). Flexicurity is a model of flexible security upon which the present labour markets should be based which link making employment more flexible with improvement of employment security. This mainly refers to groups which are in difficult circumstances that is women returning to the labour market after a break caused by having a baby, the disabled, people $50+$ and fresh graduates. This term can also be interpreted as an integrated strategy of simultaneous increase of labour market flexibility and security. A strategy which should ensure a swift transfer from the moment of completing education to commencing work and finally retiring. Flexicurity refers to looking for solutions beneficial for both parties on the labour market, i.e. employers and employees. As a concept, it is a complex approach to creating a labour market policy that binds satisfactory flexibility of contracts with ensuring security for employees in respect of keeping their jobs or finding a new one in a short period of time. It is equally important to ensure proper incomes for an employee in a period before commencing work. Such a solution may be beneficial both for employees and companies. Such flexibility means creating conditions where employees will be able to easily get or change a job, and when improvement of their qualifications shall increase employer's safety and benefits (Kuklak-Dolata, 2010, p. 146). Flexibility of this model allows to adapt to the continuously changing labour market. In its assumptions, it sees individuals at each phase of their professional and private life. On one hand it assumes flexible work organisation which facilitates combining career and private life and improving or changing professional qualifications in a short perspective, on the other it ensures social safety in case of losing jobs by providing support to those laid off by possibilities of quick requalification and to the unemployed by a good motivation system. The model is recommended by the European Union as the example to be followed by other member states. Also, the EU has found the flexicurity concept as the best method to adapt European labour markets to changes and therefore to fulfil the Lisbon Strategy objectives. The flexicurity model has become the leading element of the labour market and employment policy in the European Union which, however, does not assume creation of a uniform model in all the EU states.

\section{THE FLEXICURITY MODEL IN EUROPE}

There are currently two flexicurity models in Europe: Danish and Dutch. However, these are not the only countries where changes have been introduced to the labour market. In Germany, Austria, Belgium and Spain attempts have been made to implement concepts which bind labour market flexibility with social security, though the final result has been different in each of these states. For instance, German regulations 
guarantee employees a possibility to transfer from a full-time job to a part-time job. In Austria conditions are created for vocational mobility and attempts are made to reduce employers' costs of paying gratuities. The Belgian system stresses supporting job seekers in the transitory period by establishing vocational consultancy and supporting professional reorientation (Arczewska, 2008, p.80).

The Danish model, which is set as an example, which joins flexibility with social security was established in 1990s. The social-democrats who ruled at that time allowed employers to dismiss employees more easily but at the same time guaranteed generous benefits which allowed to survive the period of looking for a new job.

Flexicurity in Denmark is based on abandoning actions which stress employment stability in favour of high numerical flexibility which means accepting employers' freedom in employing and dismissing staff and therefore lower employment protection. This approach is counterbalanced with a high level of social protection for the unemployed and availability of activating programmes. Ability to use a full range of social benefits depends on participation in an activating programme. Obviously, the Danish model is not cheap but what is more important it is effective (Analiza..., 2011, p. 5).

The essence of the Dutch model involves development of temporary employment and part-time employment with gradual expansion of social protection over atypical forms of employment. Interest in parttime jobs comes mainly from women as they allow them to combine professional career with rising children. Within the Dutch flexicurity, part-time employees enjoy almost equal social security as full-time staff which is guaranteed by the structure of the pension scheme. Another characteristic is a dynamic growth of temporary employment agencies which act as agents in employment relations between the employee and the company. This mechanism gives employers numerical and functional flexibility and does not deprive employees of social security which is ensured by their employment relationship with an agency (Arczewska, 2008, p. 80).

Another country which attempted to introduce the flexicurity model is Spain. In the 1980s and 1990s, as a result of implemented reforms, fixed-time and part-time employment increased but only for specific groups of employees. That mainly referred to young, well-educated people who could not achieve a stable situation on the labour market and whose competencies outdated. Another group were employees with a longer employment record, with lower skills who were usually employed for an indefinite period. It should be noted that actions taken in Spain did not result in creating a flexicurity model but contributed to a division of the labour market according to the economic concept of insider-outsider. The Spanish reform resulted in establishing a structural factor of social stratification where part-time or fixed-time jobs with lower salaries/wages became available for young people, yet without any guarantee of a full-time employment. In mid-1990s Spanish authorities noticed the problem and took respective recovery actions. However, their effectiveness is limited as "the division of employees into insiders and outsiders is easier to introduce than to terminate" (Arczewska, 2008, p. 80).

\section{COMPONENTS OF THE FLEXICURITY MODEL}

In order to implement the flexicurity model, i.e. to balance flexibility and safety on the labour market, four conditions which comprise the so called flexicurity components have to be fulfilled:

1. Effective active policy of the labour market

2. Complex strategies of lifelong education

3. Modern systems of social security

4. Availability of proper (flexible and reliable) contractual arrangements 
The four components of the Flexicurity Model

\begin{tabular}{|c|c|c|c|}
\hline \multicolumn{2}{|c|}{ Flexicurity Model } \\
\hline $\begin{array}{c}\text { Active labour market } \\
\text { policy }\end{array}$ & $\begin{array}{c}\text { Complex strategy } \\
\text { of lifelong education }\end{array}$ & $\begin{array}{c}\text { Modern systems } \\
\text { of social security }\end{array}$ & $\begin{array}{c}\text { Flexible contract } \\
\text { conditions. }\end{array}$ \\
$\begin{array}{c}\text { Focused on activation of } \\
\text { and support for people in } \\
\text { particularly hard situation on } \\
\text { labour market, especially the } \\
\text { unemployed }\end{array}$ & $\begin{array}{c}\text { A process striving at continu- } \\
\text { ous increase of human capital } \\
\text { and improvement of employ- } \\
\text { ees adaptation to any changes } \\
\text { on the labour market. }\end{array}$ & $\begin{array}{c}\text { A proper support of income } \\
\text { which facilitates employment } \\
\text { and mobility on the labour } \\
\text { market. Social benefits should } \\
\text { not permanently replace } \\
\text { incomes from work. }\end{array}$ & $\begin{array}{c}\text { Legal grounds to legally use } \\
\text { flexible employment forms } \\
\text { and reduce market segmenta- } \\
\text { tion and the extent of unreg- } \\
\text { istered employment. }\end{array}$ \\
\hline
\end{tabular}

Source: author's research on the basis of: Flexicurity. Information campaign for promotion of flexible employment forms, a project co-financed by the European Union within the European Social Fund, 2011, p. 5

Bearing in mind that the flexicurity model is supposed to ensure work safety for employees on one hand, and on the other to make employment more flexible for the employer, the labour market institutions should develop the following components of this model:

1. Active market labour policy - regardless of the labour market situation, there have always been groups of people who due to various reasons have smaller chances to get and keep a job. The flexicurity model is supposed to improve the vocational situation of such people by providing them with opportunities to find employment and appropriate job. This refers to women, the disabled, the elderly or youth entering the labour market for the first time. This, however, requires support from institutions which deal with the labour market and are capable to identify best maladjustments on the labour market and react in an appropriate manner assisting in finding a job.

2. Complex strategy of lifelong education - a prerequisite for a success of the model is introduction to the educational system, as early as in kindergarten, elements which prepare young people to independently manage on the labour market and shaping awareness that the school education is the beginning of a path which leads to work. In order to keep employment and develop professionally, it is necessary to improve qualifications throughout entire life through various forms of continuing education (selfeducation, trainings, studies, internship, traineeship). A strategy of lifelong education should ensure constant ability of employees to adapt to changes and to be employed in various jobs and places.

3. Modern social security systems - the most important binder for flexicurity is ensuring safety during unemployment periods. A cohesive and transparent system of social security should be a guarantee here. It should include temporary financial support in the form of benefits and aid. This type of social security aims at balancing negative impact of job loss upon incomes of the unemployed but in amounts which should not discourage from reemployment.

4. Flexible contract conditions - the basic pillar of the approach which regulates employment relationships between employees and employers is differentiation of contract conditions in respect of employment time, place of work, remuneration rules or stability of employment. Flexible contract conditions are achieved due to a modern labour law, collective agreements and modern organisation of work (Flexicurity..., 2011, p. 5-6).

As economic analyses show, simultaneous use of the four components influences improvement of capability to employ people, increase the human capital and reduce the risk of poverty. 


\section{FLEXIBLE FORMS OF WORK}

When analysing flexicurity, attention should be paid to one of the key elements of an active labour market policy, namely atypical or flexible forms of work. In the times of such dynamic changes as globalisation of economic processes, development of information and telecommunication technology or expansion of services, the traditional model of work is being gradually abandoned. Growing competition forces companies to be flexible when choosing forms of employment and organisation of the working time. Competitiveness is based on ability to quickly react to changes or even to be ahead of them. Productive employment becomes essential, that is one which is needed and fully used by a company. It shows adaptation of the number and type of employees to quantitative, qualitative and time demand for work. Gradually, the society is changing the stereotype of employment concepts. Until now such ideas as: permanent, unchangeable, fulltime have been desired by labour market participants, now the following terms are more and more popular: flexible, dynamic, variable, mobile. Currently, companies may be more competitive where employees show flexibility, continuous search for better solutions and innovativeness. It can be more frequently observed that employees are trying to understand that evolution, observing changes occurring in the world.

The term of flexible forms of work may be defined as work performed under a legal employment relationship but provided in part-time, under non-standard time schedule or for fixed period. The term may also be understood as employment on a basis other than employment relationship. Such employment is then exempted from the labour law discipline especially in terms of working time and remuneration amount The traditional employment, understood as employment on the basis of a permanent employment contract of time is being replaced to still higher extent with flexible forms of employment (Arczewska, 2008, p. 78).

Nowadays, the adjective 'flexible' accompanies numerous nouns and often denotes ability to adapt to changing conditions of one's environment. Flexibility on the labour market is a more and more desired feature and refers to: the scope of work (readiness to take new tasks, unrelated to the current scope of obligations), the working time (often understood as a synonym of availability) and the form of contract signed with the employer. Such an approach to flexibility results in problems with discriminating between flexible and atypical solutions, positive and negative flexibility and we do not know which solutions among those frequently listed in our strategic documents and operating programmes would be helpful in activating numerous people who suffer from special difficulties related to entering and staying on the labour market (Elastyczne.., 2011, p.10).

The subject literature presents the following most popular division of flexible forms work:

1. Employment under employment contract within a classical employment relationship which includes such forms as: fixed-time contracts (for a fixed period, until completion of a given job, probationary period, substitution, part-time employment), labour leasing, telework, on-call job, job sharing.

2. Employment without employment contract which is not subject to labour law discipline, especially in respect of the working time and the place of work. This category includes: employment on the basis of civil law contracts (mandate contract, contract for specific work, agency contract) and home based work.

3. Other which do not match the aforementioned categories: outsourcing (permanent order of providing external services), self-employment, job rotation

Making employment more flexible is obviously beneficial for reducing labour costs and soothing unemployment effects. People are employed who would not get a traditional employment due to higher labour costs. On the other hand, it should be remembered that labour law objective is to protect employees. Therefore, European labour law regulations stress balance between flexibility and security. Development of flexible 
forms of work is also appreciated by employees. Atypical employment is considered a beneficial form e.g. by women who want to combine professional duties with upbringing children. Also, this is a convenient form of employment for highly-qualified staff who value their time, for the disabled for whom commuting itself is a problem and also for regular employees working within the classical pattern of employment relationship whose remuneration is low and who are forced to look for additional work (Planowania kariery Zawodowej, 2011, p.10).

In the Polish conditions, the basic and superior strategic document which specifies objectives and priorities for social and economic development and conditions which should ensure that development is the National Development Strategy 2007-2015. The Strategy sets forth objectives and identifies key areas to achieve the goals upon which national actions shall focus. Priorities approved within the strategy define essential directions and main actions which should allow to reach the main objective. The priority regarding growth of employment and improving the quality of life strongly stresses a need for promotion and use, to a higher extent, of flexible and alternative forms of employment and organisation of working time and conditions (Elastyczne formy zatrudnienia, 2009, p.6).

Flexible employment forms are still a novelty on the Polish labour market. Nevertheless, the current situation in Poland which characterises with dynamic economic and technological changes together with labour-related migration of Poles causes an increase of demand for temporary workers and other representatives of atypical forms of employment. Flexible employment is becoming attractive not only for employers. It is becoming more and more popular among employees and representatives of public services of employment. That is because its broader application may restrict unemployment and work on the black market, increase mobility and activity on the labour market and enhance competitiveness among companies as well as influence reduction of public spending on benefits for the unemployed. When it is the labour efficiency per hour which matters more and more rather than the number of hours spent in an office, an important factor to popularise non-standard forms of employment is a necessity to escalate employees' efficiency. Its growth may be achieved by reducing the number of hours spent at the workplace, allowing individual organisation of a working day which should lead to better use of employees. Differentiation of the working time is willingly accepted by staff as it allows batter adaptation of the working hours to their current needs. This allows employees to individually arrange their time, approach their tasks, work at their own pace and combine professional and private life. Then employers use the opportunities brought by flexible employment to increase company attractiveness on the labour market and to keep specialist with required qualifications in the company (Arczewska, 2008, p. 26).

Currently, entire Europe, Poland included, turns attention to flexible methods of labour and working time organisation which give a chance to: improve the quality of work, increase employment, develop competitiveness, help combine work with private life of employees. Flexible employment forms are more often perceived as a desired reaction to the current challenges on the labour market.

\section{CONCLUSION}

"Flexible forms of work" as a term operating on the labour market is difficult to define. It is often identified with a statement that these are forms of work which deviate from the typical form of employment such as a permanent employment contract. Therefore, these are atypical forms of employment whose characteristics include flexible working time and place, the form of employment, other relations between the employee and the employer. They are a truly new approach in the labour law as they more and more depart from the classical job under a permanent employment contract. They are gaining popularity as the 
Polish labour market, just like the European one, is continuously changing due to growing competitiveness, needs to introduce innovative solutions and a risk of economic crisis Facing the global economic crisis, new and unused solutions gain remarkable importance which link flexibility with security creating the so called flexicurity model. The precursor of this model on the labour market was Denmark followed by other Nordic countries. The modern labour market requires adaptation from all players who have to be ready to face big variability which demands continuous education. Qualifications become still more important condition of success on the labour market as they allow higher flexibility both for employers and employees.

It should be noted that the tendency to use flexible employment forms carries numerous benefits as it involves lower labour costs, better adaptation of the infrastructure and employment size, staff rotation and reduction of social benefits. Unfortunately, untypical employment clashes against employees' fears mainly caused by missing stability of employment as compared to the traditional model. It should though be expected that in the years to come, flexible employment shall act more and more significant role by increasing the total number of working people through activation of groups which so far have been vocationally passive.

\section{LITERATURE}

Analiza rozwiązań sprzyjajacych rozwojowi idei flexicurity w polskim systemie prawnym, Flexicurity szansą na zrównoważony rozwój rynku, Poznań, 2011.

Arczewska M. (2008), Uwarunkowania i możliwości wprowadzenia w Polsce polityki flexicurity jako koncepcji poszukiwania równowagi między elastycznością rynku pracy a bezpieczeństwem socjalnym osób zatrudnionych i bezrobotnych, Elastyczne formy pracy. Szanse i zagrożenia, ed. C. Sadowska-Smarska, Wyd. Wyższa Szkoła Ekonomiczna w Białymstoku, Białystok.

Baron-Wiaterek M. (2008), Instytucjonalno-prawne aspekty rynku pracy i promocji zatrudnienia, IPiSS, Warszawa.

Elastyczne formy pracy. Poradnik dla pracodawców, Wydawnictwo Wyższej Szkoły Ekonomicznej w Białymstoku, Białystok 2007.

Elastyczne formy zatrudnienia. Kompendium. Laboratorium elastycznych form zatrudnienia materiały edukacyjno-szkoleniowe (w) Kampania informacyjna na rzecz promocji elastycznych form zatrudnienia, Projekt wspóffinansowany przez Unię Europejską w ramach Europejskiego Funduszu Społecznego, Warszawa-Łódź, 2009.

Kukulak-Dolata I. (2010), Publiczne stużby zatrudnienia wobec koncepcji flexicurity (w) Pięciolecie członkostwa Polski w Unii Europejskiej. Zagadnienia gospodarcze i społeczne ze szczególnym uwzględnieniem polskiego rynku pracy, praca zbiorowa pod red. D. Kotlarz, AE, Katowice.

Kryńska E. ed. (2009), Flexicurity w Polsce. Diagnoza i rekomendacje. Raport końcowy z badań, Ministerstwo Pracy i Polityki Społecznej, Departament Rynku Pracy, Oficyna Wydawnicza ASPRA-JR, Warszawa.

Kryńska E. Warszawa (2008), Równowaga między elastycznościa i bezpieczeństwem na polskim rynku pracy. Jak osiagną́ flexicurity? Beck C.H., Flexicurity - między elastycznością a bezpieczeństwem na rynku pracy, Biblioteka Monitora Prawa Pracy.

Kryńska E. (2003), Wykorzystanie niestandardowych form zatrudnienia i organizacji pracy w przedsiębiorstwach polskich, Horodeński R., Sadowska-Snarska C. ed., Rynek pracy w Polsce na progu XXI wieku. Aspekty makroekonomiczne i regionalne, Instytut Pracy i Spraw Socjalnych, Wyższa Szkoła Ekonomiczna w Białymstoku, Białystok - Warszawa.

Olejniczak Z. ed. (2009), Poradnik wdrażania elastycznych form zatrudnienia, Stowarzyszenie na Rzecz Rozwoju Rynku Pracy „STOS”, Warszawa-Łódź.

Rymsza M. ed. (2006), Elastyczny rynek pracy i bezpieczeństwo socjalne. „Flexicurity” po Polsku?, ISP, Warszawa. 
Sadowska-Snarska C. (2006), Elastyczne formy pracy jako instrument ułatwiajacy godzenie Życia zawodowego z rodzinnym, Wydawnictwo Wyższej Szkoły Ekonomicznej w Białymstoku, Białystok.

Stiglitz J.E. (2004), Globalizacja, PWN, Warszawa.

Szkolenia pracodawców z zakresu elastycznych form pracy. Poradnik dla instytucji szkoleniowych, Wydawnictwo Wyższej Szkoły Ekonomicznej w Białymstoku, Białystok 2007.

Szkolenia pracowników z zakresu elastycznych form pracy. Poradnik dla instytucji szkoleniowych, Wydawnictwo Wyższej Szkoły Ekonomicznej w Białymstoku, Białystok 2007. 